\title{
THE WIND BLOWS GENTLY: REFLECTIONS ON THE HOLY SPIRIT IN THE THEOLOGY OF KH MISKOTTE
}

\author{
Ockert Meyer \\ University of Stellenbosch
}

\begin{abstract}
Not much is written about the work or the Person of the Holy Spirit in the theology of the Dutch theologian, KH Miskotte. That is partly due to the fact that Miskotte never developed a separate doctrine of the Spirit, something that is very clear when his theological works is studied. However, the moment when his so-called devotional writings (which for the sake of this paper include sermons, meditations, bible studies etc) is included in the study, one is amazed at the frequency in which the Spirit features. In this paper it is shown how his speech on the Spirit is fully consistent with the wider aim of his theology, as well as how it defines the vitally important pneumatological moment in the ordinary life.
\end{abstract}

\section{Introduction}

It has more or less become the custom to relate the activity of the Holy Spirit to the mighty signs of Acts 2. Especially through the influence of the Charismatic reformation during the previous century and perhaps as a result of the barrenness of the modern church life an expectation has developed to clearly and definitely see and hear and feel. Much of this expectation centres on the events of Acts 2: the sounds of a mighty windstorm, the flames or tongues of fire and the experience to be understood.

It is not difficult to understand why this expectation has shaped the way that we think and speak about the Holy Spirit. With these perspectives in mind, I am convinced that we'll find it fruitful and perhaps even necessary to dwell for a moment on the insights that Miskotte's theology bears.

\section{In dialogue with modern man}

KH Miskotte was a Dutch theologian (1894 - 1976), a genius exponent of the Reformed tradition and both a man of his time and ahead of his time. Virtually his whole theological oeuvre exhibits his lifelong fascination with writers, poets, musicians and culture in a very broad way. His successor at the university of Leyden, Hendrikus Berkhof, has spoken of the two poles of his life work, theological and cultural, and this bipolarity "coupled with a mystical faith and a superior intellect" he says, "has made Miskotte a man of authority in all areas of the church and the culture of the Netherlands". 1

His theology is marked by an intense interest in and focus on the Old Testament. This had little to do with a mere interest in Judaism, but was driven by a deep pastoral concern for the people of his time. "To be able to bring out clearly this "doctrine of God" in a time when "the gods are silent" could be an act of humanity par excellence" he says in the foreword of the same book. ${ }^{2}$ The question that kept him busy was: How can you preach to people on the way to nihilism? Is there anything that you can still say or proclaim in an

1. Doberstein in the translator's introduction of When the gods are silent, (WGS), xv. New York / London, 1967.

2. Ibid, 114 . 
atmosphere of atheism? What can we, as church say, when faced with the silence of the gods?

In trying to answer these questions Miskotte refers us to the Old Testament. In the spirit of Barth he wants to relate the Old Testament and the New Testament as being respectively the period of expectation and the period of recollection, as an equal and twofold witness to the exclusive revelation, that is, to "God himself as he unrepeatedly and irrevocably unites himself with human life in Jesus Christ at one point in time."

The vocabulary of the Old and the New Testament have the same Object. In this respect and to this extent they are one with each other. "The unity, therefore, does not lie in the form, not even in the content of the texts, but rather in that which the content (along with the form) attests... God himself, this God who is different from all gods, before whom the godhead vanishes as a dream, is himself the power that brings into a unity all the love and devotion, all the living and the striving of man which is directed through Him to Him." 3 In the centre of this revelation is the unutterable Name.

Hence we can say that the point at which Miskotte starts his dialogue with modern man is always with the self-revelation of God. This is the " $a$ " of the biblical $a b c$. This is also the point where we meet the Spirit, the Holy Spirit who is both the Revelator and the Revelation. Exactly this is also the point where we need the Spirit, because man is simply bewildered by the unreliability and the characterlessness of God, for it is right here - at the confusion between God and the gods, at an isolated and hypostasized doctrine of God - here that the feeling of God's absence has its origin. "Here everything depends on the order and sequence, on the right kind of connection and separation.... When we start from the infinity of God, we destroy the knowledge of God's special Name, for then right from the start we destroy the decisive character of the encounters with God and end up in a polyinterpretability that is precisely characteristic of that which is silent."4

This consistency covers all aspects of Miskotte's theology. As far as our knowledge of God is concerned: there is a definite sequence, a theological order which always runs from the special revelation to the general revelation. "In the entire Scriptures as the holy teaching of God our knowledge goes from the peculiar to the general, from the quality to the quantity, from the moment to the view over the centuries, from the special Name to the divinity of God, from the special power, revealed in cross and resurrection to the omnipotence in the world, from the special presence in the temple, the presence in the Word and sacrament to the omnipresence..."5

\section{The heart of the matter}

It is reasonable to deduct that if there is a specific sequence there must also be a very particular starting point. This holds true for the way that Miskotte thinks about God and his revelation.

The heart of the matter is God himself. God reveals Himself. Everything starts at the proclamation: "I am JHVH your God."(Ex 20:1) And the proclamation is echoed by the confession: “ Israel listen: JHWH is our God, JHWH alone. (Deut 6:4)

\footnotetext{
3. Ibid, 218.

4. Bijbels $A B C, 126$. Ten Have, Baarn, 1966.

5. Ibid, 34 .
} 
The Name creates the ability to address. " 6 "The Lord our God, He alone is God-Under all heaven there is no other name for men to call upon to save them ${ }^{7}$ No one can say that Jesus is Lord, except by the Holy Spirit" 8

To allow God to be God, is nothing else than the confession of the Holy Spirit. ${ }^{9}$ One can also say this in another way: The confession of the Holy Spirit, is nothing else than to allow God to be God. The Holy Spirit does not introduce a new revelation, but places the one revelation - in Miskotte's language the only revelation - present in our lives. ${ }^{10} \mathrm{He}$ says:

The essential thing however, remains the unutterable Name, which binds the Old Testament to the New... It is a matter of him who is present as God-with-us, as he wills to be present. It has to do with him whose deepest singular self is at the same time his revealed manifestation. It has to do with him who is nowhere more Spirit than he is in his earthly being, who deals with us humanly - humanly not despite his divinity, but by virtue of his divinity ${ }^{11}$

Thus we can see that Miskotte makes it clear that the Holy Spirit does not only proceed from God the Father and God the Son, but the Holy Spirit also attests that JHWH is indeed God and that Jesus is indeed the Christ.

\section{The heart sees everywhere}

In one of his sermons ${ }^{12}$ Miskotte calls the Spirit the "Transcendence" in which every sense of meaning is founded. He is the existence and the kernel of existence and the meaning of our existence. What does this mean? According to Miskotte it means that the Holy Spirit attests to, guarantees and represents the heart of all truths: that we are. This affirmation of human life rests fully in the revelation of Jesus Christ. The life that was unlocked through Jesus Christ has become our life.

This creates the point of orientation from where reconnaissance over the full theological landscape is possible. Very often in his writings one comes across the following, virtually untranslatable formulation: "The heart sees everywhere, the unique is the universal and the seed is the only miracle"13 This means that somewhere there is something, an essence of knowledge, a full scope of possibilities and this deepest centre is to be found in the friendship that the Spirit creates between God and man. This is the relationship from Heart to heart, the silent receptiveness and attentiveness for the voice of God. This silence is the heart of human life, it is also the heart of the universe. The person in hidden communion with God represents pars pro toto the whole world: what is true and real for him or her, holds true and real for the whole world. Hereby it is clear that the small personal world is very important: the meaning of one, unique life consists and conceals the meaning of history. "This inner experience of faith also embraces encounter with the other creatures, contact with the mystery of creation. The fact that in the depth of its origin the creation is a

6. Acts 4:12.

7. De Kern van de Zaak, 113. Callenbach, Nijkerk, 1950.

8. Ibid, 115 .

9. Ibid, 119 .

10. WGS, 339 .

11. Preken en meditaties, Verzameld werk 3 (VW 3). Kok, Kampen,1997. Sermon on John 16: 8-11.

12. "De Kern ziet wijd, het unieke is het universele, het zaad is het enige wonder." A saying from the pen of Dr GH van Senden., $V W 3,159$.

13. Miskend majesteit, 12. Callenbach, Nijkerk, 1969 Compare also Van der Velden: KH Miskotte als prediker. Een homiletisch onderzoek, 118. Boekencentrum, Gravenhage, 1984.

14. WGS, 265. 
blessing cannot be demonstrated within the framework of a world view, but in the experience of faith..."

Thus we can see it is the Holy Spirit that creates and shapes the continuity between God, man and history/world/creation. This is however not a self-evident or natural continuity, it is a continuity that is time and time again a miracle - the miracle of the seed. It is therefore possible to see the traces of God's favour in the world, in the ordinary, political and cultural world. It is indeed the unique that has spread universally. ${ }^{16}$

\section{The pneumatological moment in the ordinary life $\mathrm{e}^{17}$}

It would not be misleading to call Miskotte a theological existentialist, in as far as his complete theological consciousness is taken up, is fascinated and is focussed on our existence in the world. The centre of this existence is found in the so-called ordinary life.

Miskotte says: "...it is precisely the Name which casts us out of the detached and scheming attitude of the spectator... The superior power of the Name reveals itself in the fact that finally something comes upon us and we finally come to something. It does not take us out of the world, it does not pin us down to the world - it rather drives and pushes us out into life."18 Exactly this is the work of the Holy Spirit, it is the fruit of Pentecost: we are being lead back into the ordinary life. ${ }^{19}$ It is He who gives us a taste for life, ${ }^{20}$ not in the sense that He gives our existence a sugar-coating, but in the sense that He reveals our selfdeception. He reveals who we really are: our vulnerability, our anxiousness. ${ }^{21}$ But the same Spirit who reveals, is also the Spirit who heals. Through the pneumatological moment in the ordinary life the misery of our existence is both revealed and healed. ${ }^{22}$ It is the Spirit of Christ who leads us to where the Spirit of the Creator is present in the creation.

In the theology of Miskotte no special or sacral sphere is reserved for the so called spiritual life, because it is through the ordinary life that we are initiated into a truly spiritual life or a life in obedience to God. The presence of God is to be found exactly where we are, in our immediate proximity, in the ordinary life. ${ }^{23}$ It is, however, important to note that this does not mean that the ordinary life as such could be seen as revelation . Quite the contrary: where the Revelation has taken place, only there life appears "ordinary". 24 It is again important to note that the ordinary life is in Miskotte's understanding not only the setting in which the Revelation takes place, but much more: it is indeed the realising of the Revelation. $^{25}$

God is certainly hidden in the ordinary life, but it is still there where He is to be found and served. This means that, in Miskotte's understanding, the ordinary life is a life in the covenant, to such an extend that there could be no differentiating between the "natural" and

\footnotetext{
15. Ibid, 159 .

16. The only reference to the Holy Spirit in the literature on Miskotte bears this title: Het pneumatisch moment in het gewone leven. (JH Meijer).

17. $W G S, 71,72$.

18. VW 3, 293.

19. Ibid, 238.

20. Ibid, 292.

21. Compare ibid,354.

22. Als een die dient..., 54. Ten Have, Baarn, 1976.

23. Het gewone leven/Antwoord uit het onweer. Verzameld Werk 10, 318. Kok, Kampen, 1984.

24. Cf: Van der Sar: Het besondere van het gewone, in den Hartog, GC Neven (eds): Miskotte: Hoofdlijnen van zijn theologie, 88. Kok, Kampen, 1993.

25. VW 10, 525 .
} 
the "spiritual" things, because the natural belongs to the spiritual, exactly the same way as the spiritual belongs to the natural.

From this follows that we can never use the Bible as a kind of recipe book through which we can autonomously deduct or merely apply the Scriptural truths. The Holy Spirit has to apply the Word on a daily basis to our lives. To live means to go from decision to decision, to be abandoned to God's guidance. ${ }^{26}$ Only in terms of these resolutions, the true day to day guidance of the Spirit, can we speak about the ordinary life as spiritual life. This is the real and true sign of God's faithfulness as it is to be found between our memory and expectation of the one Revelation. ${ }^{27}$

This brings us to the point where we can say that Miskotte's understanding of the Holy Spirit begins to take a distinctive frame. In accordance with the Old Testament teaching where the "spirit" remains close to the earth, ${ }^{28}$ the Holy Spirit is the Spirit of Life. Not life in a mere biological sense of the word, but life in the sense of the hidden communion in the ordinary life.

The Spirit is not in the first place the One who is revealed through the mighty signs, but the One who is present in a hidden way. ${ }^{29} \mathrm{He}$ is hidden, but in the sense that He conceals Himself. Indeed, it is a gentle ${ }^{30}$, and often inconspicuous wind, that gives and permeates life and fills the world.

Miskotte points out that on Pentecost, apart from the accompanying signs, nothing is seen. In the centre of these events we find no crib, no cross and not even an open grave. Here in the centre we encounter the Word: the festive part of Pentecost is in the comprehensible word, the preaching of a Word - the Word about Christ - as the entrance to life. ${ }^{31}$

\section{The Spirit as the Giver of virtues}

The Spirit is not only the giver and sustainer of life. The Spirit is also the One who transforms life and this transformation is enabled and is driven by the gifts, the virtues that the Spirit bestows on us.

The Holy Spirit is the power to prophesy. Therefore He conceals Himself in not only in the Word that is spoken, that is proclaimed, but also in the life of the church. Hence He is everywhere, but nowhere to be seen. The important question is: What is the content of the prophecy, what does the invisible Inspiration give and inspire? Miskotte's answer to this is that the heart of the church's prophecy is the expectation of faith, hope and love. These are the gifts or the virtues of the Spirit. But again, it is not faith, hope and love in a general sense, the virtues are within the reach of anybody. ${ }^{32}$

It is fascinating to see again how the heart of the matter sees everywhere. Here it transpires again how the universal is dependant on the unique, how the general proceeds from the peculiar. Faith is namely faith in Jesus Christ; hope is the hope for the new heaven

\footnotetext{
26. Idem, 658 .

27. WGS, 357 .

28. $V W 3,20$.

29. A reference to the description of the presence of God in 1 Kings 19:12. "The Lord was not in the wind, nor in the earthquake or the fire. He was however in the sound of a gentle whisper". (The Living Bible) Here the translation of the new Afrikaans Bible remains unsurpassed. "Die Here was in die fluistering van die windstilte")
}

30. VW 3, 531.

31. Ibid, 25-29.

32. Ibid, 32/33. 
and earth and the love is the love for the community of the saints. The love for the church, the hope for the second coming and the faith in Christ; none of these things comes naturally. They are gifts of the Spirit.

The moment that these gifts are given to the ecclesia, something else happens. The Inspirator inspires the virtues again. And thus the love does not stay in the church, but grows to the expectation of a greater brotherhood and sisterhood, the hope is transformed into the hope for a new world order and the faith becomes the truly catholic and Christian faith.

These virtues do not only proceed from the Spirit, but are also sustained by the Spirit. Since Pentecost we are told: faith, hope and love remain...Exactly this is also the consolation of the Comforter: Faith is part of the believer, but it is also greater than the believer, the hope goes further than our hope and the love reaches much wider than our initiatives. Love, hope and faith are in us, but not from us. Our love, hope and faith are nothing but a participation in the Holy Spirit, a participation in the love, the hope and the faith. Therefore our love, hope and faith are miracles, an immaculate conception, received from the Holy Spirit. ${ }^{33}$

Truly, the heart sees everywhere, the unique is the universal and the seed is the only miracle!

\section{The Spirit of the Child}

Pentecost is, to conclude, a universal Christmas. The Spirit-Child is poured out again on the streets of Jerusalem. When we receive the Spirit, we receive the Spirit of the Child. The Holy Spirit is Jesus who has come back, He is the Spirit who calls : Abba Father!

On Pentecost God has sent his Child; however, this time not to redeem but to bless. ${ }^{34}$ What is the Holy Spirit? To this question Miskotte answered: He is thát in our piety who makes our piety more than our piety, He is the blessing. ${ }^{35}$ 